\title{
Alteration of Human Erythrocyte Membrane Properties by Complement Fixation
}

\author{
John R. Durocher, Jon P. Gockerman, and Marcel E. Conrad \\ From the Department of Hematology, Walter Reed Army Institute of Research, \\ Walter Reed Army Medical Center, Washington, D. C. 20012
}

A B S T A C T Erythrocyte survival studies of complement-coated radiolabeled erythrocytes have shown rapid removal of these cells from the peripheral blood with a return of these cells into the circulation within a few hours. We studied complement-coated human erythrocytes and measured surface charge and deformability, two parameters believed to be important in erythrocyte survival. Erythrocytes were coated with complement by two in vitro techniques: the addition of $(a)$ low ionic strength sucrose, and (b) IgM cold agglutinins.

Erythrocytes obtained from three patients with cold agglutinin disease were used as a source of in vivo complement-coated cells. No difference was found in surface charge as measured by electrophoretic mobility between erythrocytes from normal subjects and complementcoated erythrocytes from any of the three sources. When deformability was measured by filtration through $3-\mu \mathrm{m}$ polycarbonate sieves, marked decreases in deformability were found in complement-coated erythrocytes. The filtration returned toward control levels by incubating the complement-coated erythrocytes in serum for $1 \mathrm{~h}$ and correlated with decreases in immune adherence. Using screen filtration pressure as a measure of deformability, a positive correlation between number of $\mathrm{C} 3$ molecules per erythrocyte and decreased deformability was found. $\mathrm{C} 3 \mathrm{~b}$ appeared responsible for the decreased deformability of the erythrocytes, since conversion of C3b to C3d resulted in a return of deformability toward normal. The

This work was reported in abstract form at the annual meeting of the American Federation for Clinical Research, Atlantic City, N. J., 29 April 1973 (Clin. Res. 21: 552).

Dr. Durocher's present address is Department of Medicine, Pennsylvania Hospital, Philadelphia, Pa. 19107; Dr. Gockerman's present address is: Department of Medicine, University of Kentucky Medical Center, Lexington, Ken. 40505; Dr. Conrad's present address is: Director, Division of Hematology-Oncology, University of Alabama at Birmingham, Birmingham, Ala. 35294.

Received for publication 17 April 1974 and in revised form 25 November 1974.

The Journal of Clinical Investigation Volume 55 April 1975.675-680 data suggested that the sequestration of complementcoated human erythrocytes in the microvasculature can be explained in part by decreased deformability and changes in immune adherence.

\section{INTRODUCTION}

Complement-fixing antibodies adversely affect erythrocytes in vivo either by the production of a membrane lesion resulting in acute osmotic intravascular lysis, or by inducing a membrane change allowing retention and extravascular destruction of the altered erythrocyte by the reticuloendothelial system. Survival studies of erythrocytes coated with antibody and complement, such that there was little intravascular lysis, have shown rapid sequestration of these cells in the microvasculature and reappearance of these erythrocytes in the circulation within several hours $(1,2)$. It has been postulated that the temporary sequestration involved the binding of complement-coated erythrocytes to $\mathrm{C} 3 \mathrm{~b}$ receptors on macrophages with subsequent modification of active $\mathrm{C} 3 \mathrm{~b}$ by a serum $\mathrm{C} 3 \mathrm{~b}$ inactivator (C3bINA), ${ }^{1}$ causing release of the cells into the general circulation (3). We studied two membrane biophysical parameters of human erythrocytes possibly associated with the sequestration phenomena, surface charge and deformability, and the influence of complement on these parameters.

\section{METHODS}

Complement fixation. Blood was collected from healthy laboratory personnel and used within $12 \mathrm{~h}$ of collection. The erythrocytes were washed three times in a Veronalbuffered saline solution ( $\mathrm{pH} 7.4$ ) containing $0.1 \%$ gelatin, $1.5 \times 10^{-4} \mathrm{M} \mathrm{Ca}^{++}$, and $0.5 \times 10^{-3} \mathrm{M} \mathrm{Mg}^{++}\left(\mathrm{VBS}-\mathrm{G}_{-} \mathrm{M}^{++}\right.$). Blood was drawn from patients with chronic cold agglu-

\footnotetext{
${ }^{1}$ Abbreviations used in this paper: C3bINA, C3b inactivator; VBS-G-EDTA, Veronal-buffered saline solution containing $0.1 \%$ gelatin and $0.015 \mathrm{M}$ EDTA; VBS-G-M ${ }^{++}$, Veronal-buffered saline solution containing $0.1 \%$ gelatin, $1.5 \times 10^{-4} \mathrm{M} \mathrm{Ca}^{++}$, and $0.5 \times 10^{-3} \mathrm{M} \mathrm{Mg}^{++}$.
} 
tinin disease into a warm syringe and defibrinated at $37^{\circ} \mathrm{C}$. The cells and serum were separated by centrifugation at $37^{\circ} \mathrm{C}$. The cells were then washed three times with VBS$\mathrm{G}-\mathrm{M}^{++}$at $37^{\circ} \mathrm{C}$. Complement was attached to the erythrocytes by low ionic strength sucrose or serum from patients with cold agglutinin disease containing an IgM anti-I antibody. For low ionic strength complement fixation, a buffered sucrose solution ( $\mathrm{pH} 6.1$ ) was incubated at $37^{\circ} \mathrm{C}$ with varying concentration of erythrocytes in VBS-G-M ${ }^{++}$ and isologous serum for $30 \mathrm{~min}(4)$. Serum heated at $56^{\circ} \mathrm{C}$ for $30 \mathrm{~min}$ to inactivate complement was used as control serum. Erythrocytes were then washed three times with VBS-G-M ${ }^{++}$. When IgM complement fixation was used the serum containing the antibody was diluted $1: 20$ with VBS-G-M $\mathrm{M}^{++}$. Then equal amounts of an erythrocyte suspension containing $1 \times 10^{8}$ cells, diluted antibody, and fresh autologous serum were incubated for $30 \mathrm{~min}$ at $4^{\circ} \mathrm{C}$ and 30 min at $37^{\circ} \mathrm{C}$; they were then washed once with a Veronalbuffered saline solution ( $\mathrm{pH} 7.4)$ containing $0.1 \%$ gelatin and $0.015 \mathrm{M}$ EDTA (V.BS-G-EDTA), and three times with VBS-G-M $\mathrm{M}^{++}$at $37^{\circ} \mathrm{C}$. Heated serum and VBS-G-M ${ }^{++}$ were used as a control.

Attachment of $\mathrm{C} 3$ to the erythrocytes was determined by direct Coombs' test using rabbit antihuman C3 antiserum. C3 antiserum was made by the method of Mardiney and Müller-Eberhard (5) and by immunizing rabbits against purified human $\mathrm{C} 3{ }^{2}$ The antisera were absorbed with pure monoclonal IgG coupled to Sepharose-4 B by the cyanobromide technique (Pharmacia Fine Chemicals, Inc., Piscataway, N. J.). The antisera showed one line on immunoelectrophoresis against fresh human serum, thus detecting $\mathrm{C} 3 \mathrm{~b}$, and did not agglutinate erythrocytes heavily coated with anti-D IgG. The antiserum detected C3d after immunoelectrophoresis of aged human serum.

Quantitative measurements of the number of molecules of C3 on the erythrocyte were performed by the technique of Borsos and Leonard (6). A standard anti-C3 inhibition curve was made by diluting the same normal serum sample kept at $-70^{\circ} \mathrm{C}$ after adsorption with sheep cells. The C3 level of this serum was determined by radial immunodiffusion using anti-C3 plates (Behring Diagnostics, Sommerville, N. J.). A minimal estimate of the number of C3 molecules per erythrocyte was calculated by comparing the degree of inhibition of lysis by a C3-coated erythrocyte to that produced by measured amounts of $\mathrm{C} 3$; the number of nanograms of $\mathrm{C} 3$ that caused an equivalent inhibition was determined. Assuming an approximate mol wt for C3 of 185,000 and counting the number of erythrocytes on a Coulter Model B counter (Coulter Electronics, Inc., Hialeah, Fla.), a minimal estimate of the number of C3 molecules per cell can be made. Methods similar to those described by Logue, Rosse, and Adams were used to estimate the number of $\mathrm{C} 3 \mathrm{~b}$ and $\mathrm{C} 3 \mathrm{~d}$ sites (7). Indicator sheep erythrocytes coated with fresh complement were used to measure $\mathrm{C} 3 \mathrm{~b}$, whereas the same complement-coated erythrocytes treated with trypsin were used to estimate C3d.

To remove the immune adherence activity of $\mathrm{C} 3 \mathrm{~b}$, erythrocytes at a concentration of $5 \%$. were reincubated at $37^{\circ} \mathrm{C}$ in autologous sera diluted $1: 2$ with VBS-G-M $\mathrm{M}^{++}$for 90 min. The cells were washed three times in VBS-G-M $\mathrm{M}^{++}$ and used in deformability studies. Control specimens included untreated cells and erythrocytes incubated in VBS$\mathrm{G}-\mathrm{M}^{++}$. Immune adherence was evaluated by use of the column technique of Logue, Rosse, and Adams (7). $50 \mathrm{ml}$

${ }^{2}$ Purified human C3 was the gift of Dr. Gerald L. Logue, National Naval Medical Center, Bethesda, Md. of blood was collected in a syringe containing 1,000 U heparin and $15 \mathrm{ml}$ of plasmagel (Laboratorie Roger Bellon, Neuilley, France), and allowed to sediment for $30 \mathrm{~min}$ at room temperature. The leukocyte-rich plasma was removed and the cells counted. The cells were sedimented at $70 \mathrm{~g}$ for $10 \mathrm{~min}$ at $4^{\circ} \mathrm{C}$ and resuspended in the supernatant plasma at a concentration of 30,000 cells $/ \mathrm{mm}^{3}$. $3 \mathrm{ml}$ of the suspension was placed in a $1.4-\mathrm{g}$ glass wool column that was previously washed eight times with VBS-G-M $\mathrm{M}^{++}$. The cells were incubated at $37^{\circ} \mathrm{C}$ for $30 \mathrm{~min}$ and the columns washed with $16 \mathrm{ml}$ of V.BS-G-M $\mathrm{M}^{++}$at $37^{\circ} \mathrm{C}$. The erythrocytes to be studied were diluted at a concentration of $0.2 \%$ and $2 \mathrm{ml}$ added to the column. These were incubated for $30 \mathrm{~min}$ and the columns washed with VBS-G-M $\mathrm{M}^{++}$at $37^{\circ} \mathrm{C}$. The effluent from the column was collected and lysed with saponin. The percent of cells adhering to the column was calculated by measurement of the hemoglobin concentration in the effluent. The percent binding of the controls was subtracted from the test sample to give "percent immune adherence."

Surface charge. Surface charge was quantified from measurements of the electrophoretic mobility of erythrocytes in a Zeiss cytopherometer (Carl Zeiss, Inc., N. Y.) (8) fitted with platinum electrodes. The erythrocytes were washed three times with $0.145 \mathrm{M}$ sodium chloride and suspended in a mixture of 1 vol of $67 \mathrm{mM}$ Sorensen's buffer ( $\mathrm{pH} 7.2)$ and 4 vol of $5 \%$ sorbitol (9). At least 10 cells were timed in the front stationary plane before and after reversal of polarity at $23^{\circ} \mathrm{C}$. The electrophoretic mobility was expressed as micrometers per second per volt per centimeter \pm 1 SD. Three patients with cold agglutinin disease were also studied. Additional studies were performed using the buffer described by Okada, Kojima, Yoshida, and Nishioka (10) containing $0.15 \mathrm{mM} \mathrm{CaCl}$ and $0.5 \mathrm{mM} \mathrm{MgCl}_{2}$

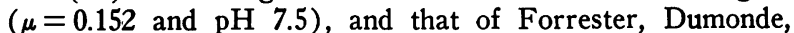
and Ambrose (11) with $\mathrm{NaCl}, \mathrm{KCl}$, and $10 \mathrm{mM} \mathrm{Ca}{ }^{++}$ $(\mu=0.150$ and $\mathrm{pH} 7.0)$. For these studies the electrophoretic buffer was substituted for saline in the prior wash. For study of the effect of $\mathrm{pH}$ changes in electrophoretic mobility, Forrester's buffer was used and the $\mathrm{pH}$ changed with $0.15 \mathrm{M} \mathrm{HCl}$ or $\mathrm{NaOH}$.

Erythrocyte deformability. The erythrocytes and suitable controls were washed three times with freshly prepared Ringer's solution buffered with $12 \mathrm{mM}$ Tris ( $\mathrm{pH} 7.4$ ) containing $0.25 \%$ albumin (12), then adjusted to a $2 \%$ cell suspension. Our measure of deformability was the time in seconds required for $2 \mathrm{ml}$ of the $2 \%$ erythrocyte suspension to pass through 3- $\mu \mathrm{m}$ polycarbonate filters under a constant negative pressure of $10 \mathrm{~cm}$ water. All samples were measured in duplicate. Timing was stopped if the sample took longer than $400 \mathrm{~s}$. Three patients with cold agglutinin disease were studied on seven different occasions. In addition, $2 \%$ erythrocyte suspensions were filtered through $3-\mu \mathrm{m}$ polycarbonate filters with a constant flow rate (13) using a modified Swank SFP apparatus (Control Laboratories, Bangor, Maine). The measure of deformability was the pressure (millimeters mercury) recorded after $2 \mathrm{ml}$ of the suspension had passed through the filter minus the pressure produced by the same volume of buffer.

Other studies. Mean corpuscular volume was calculated from the microhematocrit and erythrocyte counts done with a Coulter Model B counter (Coulter Electronics, Inc., Hialeah, Fla.) and expressed as cubic micrometers \pm 1 SD. ATP levels (14) were expressed as micromoles ATP per milliliter of packed erythrocytes \pm 1 SD. Quantitative osmotic fragility was performed using buffered saline solutions (15). Heinz body stains were made with methyl violet. 
TABLE I

Electrophoretic Mobility of Complement-Coated Erythrocytes

\begin{tabular}{ccc}
\hline \multicolumn{1}{c}{ Method } & Control & $\begin{array}{c}\text { Complement- } \\
\text { coated }\end{array}$ \\
\hline & \multicolumn{2}{c}{$\mu / s / V / c m \pm 1 S D$} \\
Low ionic strength $(20)^{*}$ & $2.07 \pm 0.04$ & $2.08 \pm 0.03$ \\
IgM cold agglutinin (3) & $2.07 \pm 0.04$ & $2.06 \pm 0.05$ \\
Cold agglutinin disease (3) & - & $2.08 \pm 0.02$ \\
\hline
\end{tabular}

* Number of samples.

\section{RESULTS}

Electrophoretic mobility. There was no significant difference in electrophoretic mobility in phosphate-sorbitol buffer between normal erythrocytes and those fixed with complement in vitro (Table I). The presence of complement on the cells was confirmed by a direct Coombs' test using rabbit antihuman C3 antibody. The electrophoretic mobility of in vivo complement-coated erythrocyte from three patients with cold agglutinin disease fell within the control range.

The study of in vitro complement-coated erythrocytes was repeated, using high ionic strength buffers with divalent cations (Table II). The low ionic strength method of complement attachment was used. Again, there was no difference in net negative surface charge between normal and complement-coated erythrocytes. No difference was seen in a $\mathrm{pH}$-electrophoretic mobility curve between $\mathrm{pH}$ 4-9 for normal and complement-coated erythrocytes. Reduction of $\mathrm{pH}$ below 4 produced inconsistent results because of rapid hemolysis.

Deformability. Complement-coated human erythrocytes had decreased deformability as measured by filterability through 3- $\mu \mathrm{m}$ polycarbonate sieves (Table III). This effect was independent of the method of complement fixation, i.e., low ionic strength or IgM cold agglutinin. The results using a cold agglutinin for complement fixation were independent of variations in antibody or fresh serum concentration during the incubation. The effect

TABLE II

Electrophoretic Mobility of Complement-Coated Erythrocytes in Different Buffers

\begin{tabular}{ccc}
\hline Buffers & Controls & $\begin{array}{c}\text { Complement- } \\
\text { coated }\end{array}$ \\
\hline & \multicolumn{2}{c}{$\mu / s / V / c m \pm 1 ~ S D$} \\
Phosphate-sorbitol (8)* & $2.06 \pm 0.04$ & $2.08 \pm 0.03$ \\
$\mathrm{VBS}+\mathrm{Ca}^{++} / \mathrm{Mg}^{++}(6)$ & $1.36 \pm 0.03$ & $1.33 \pm 0.04$ \\
$\mathrm{Na}^{+} / \mathrm{K}^{+} \mathrm{Cl}^{-}+\mathrm{Ca}^{++}(7)$ & $1.22 \pm 0.04$ & $1.21 \pm 0.05$ \\
\hline
\end{tabular}

* Number of samples.
TABLE III

Deformability of Complement-Coated Erythrocytes

\begin{tabular}{lll}
\hline \multicolumn{1}{c}{ Method } & Control & $\begin{array}{c}\text { Complement- } \\
\text { coated }\end{array}$ \\
\hline & \multicolumn{2}{c}{$s \pm 1 S D$} \\
Low ionic strength (20)* & $11.2 \pm 2.9$ & Range 25 $->400$ \\
IgM cold agglutinin (4) & $11.3 \pm 0.7$ & $132.3 \pm 80.1$ \\
Cold agglutinin disease (7) $\ddagger$ & $10.4 \pm 2.1$ & Range 18.2 $->400$ \\
\hline
\end{tabular}

* Number of samples.

$\ddagger$ Three patients measured on different days; controls are normal people.

was not altered by washing the cells with $0.015 \mathrm{M}$ EDTA-VBS buffer or incubating the cells for $2 \mathrm{~h}$ at $37^{\circ} \mathrm{C}$ in VBS-G-M ${ }^{++}$. Flow rates $(2 \mathrm{ml} /$ filtration time) ranged from almost one-half control to nonfilterable. These changes could not be explained by differences in either ATP levels, mean corpuscular volume, osmotic fragility, presence of intracellular accretions, changes in morphology as assessed by wet preparations under phase microscopy, or agglutination.

We then correlated the number of $\mathrm{C} 3$ molecules per erythrocyte to changes in deformability. Since filtration times greater than $400 \mathrm{~s}$ included samples that were not filterable along with those in which less than $2 \mathrm{ml}$ filtered, a correlation coefficient with $\mathrm{C} 3$ could not be calculated from the data obtained by this technique. Therefore, a modified Swank screen filtration apparatus was used, using $3-\mu \mathrm{m}$ polycarbonate sieves as a screen. As shown in Fig. 1, the amount of $\mathrm{C} 3$ bound to erythrocytes correlated positively with the filtration pressure $(r=0.725, P=0.001)$.

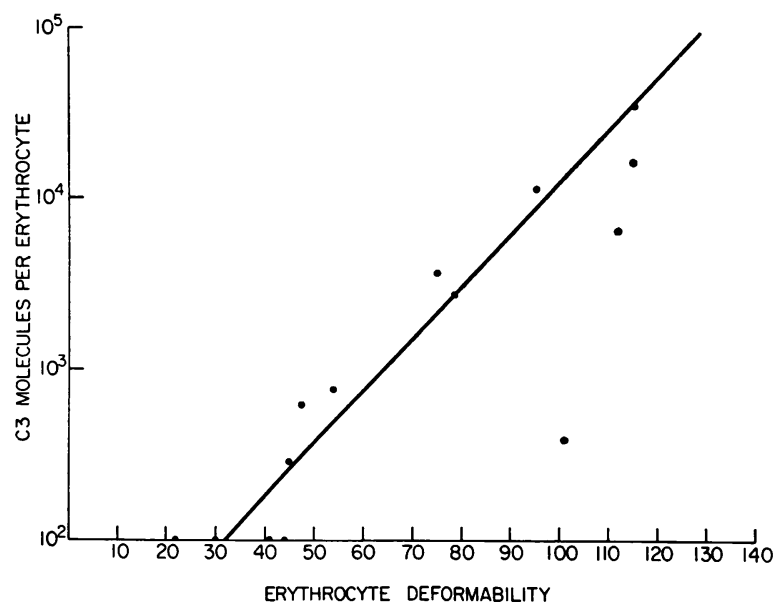

FIGURE 1 Relationship of number of C3 molecules per erythrocyte to deformability. Number of C3 molecules expressed on log scale. Deformability expressed as filtration pressure (millimeters mercury) using modified Swank SFP apparatus. $r_{16}=0.725, P=0.001$. 
TABLE IV

Effect of C3 Inactivation on Erythrocyte Deformability

\begin{tabular}{|c|c|c|c|}
\hline & $\begin{array}{l}\text { Filtration } \\
\text { time }\end{array}$ & $\begin{array}{c}\text { Immune } \\
\text { adherence }\end{array}$ & $\begin{array}{r}\text { Reduction } \\
\text { in immune } \\
\text { adherence }\end{array}$ \\
\hline Preincubation & $s \pm 1 S D$ & $\%$ & $\% \pm 1 S D$ \\
\hline $\begin{array}{l}\text { Control (4)* } \\
\text { Complement-coated (4) }\end{array}$ & $\begin{array}{c}10.9 \pm 1.6 \\
212.8 \pm 72.3\end{array}$ & $\begin{array}{c}1 \\
14 \pm 3\end{array}$ & $\overline{-}$ \\
\hline $\begin{array}{l}\text { Postincubation } \\
\text { Control (4) } \\
\text { Complement-coated (4) }\end{array}$ & $\begin{array}{l}12.5 \pm 0.7 \\
23.3 \pm 8.8\end{array}$ & $\begin{array}{c}1 \\
6 \pm 3\end{array}$ & $\frac{-}{62 \pm 15}$ \\
\hline
\end{tabular}

* Numbers in parenthesis are the number of samples.

Bound C $3 \mathrm{~b}$ was inactivated by incubation in serum and the inactivation was monitored by diminished immune adherence to leukocytes suspended in a glass wool column and increases in measurable $\mathrm{C} 3 \mathrm{~b}$ to $\mathrm{C} 3 \mathrm{~b}$ sites on erythrocytes. As shown in Table IV, filtration time of complement-coated erythrocytes returns toward control levels after C3b inactivation, and correlates with reduction in immune adherence. In all cases, binding of control erythrocytes to the column was less than $10 \%$. Heated serum also was able to return the filtration time toward control levels. The reduction in immune adherence in Table IV was associated with a $97 \%$ mean reduction in C3b molecules per cell and a $96 \%$ mean increase in C3d molecules per cell.

Abnormalities in erythrocyte filtration time of three patients with chronic cold agglutinin disease correlated with the patients' clinical status (Table V). J. B., who was the most seriously ill (with anemia, jaundice, reticulocytosis, and marked cold intolerance), had marked filtration abnormalities both with 3 and $5-\mu \mathrm{m}$ filters, whereas C. McD. was not symptomatic and had only a minor abnormality in filtration time through $3 \mu \mathrm{m}$ filters.

\section{DISCUSSION}

The temporary sequestration in the microvasculature of complement-coated erythrocytes has been described in previous investigations. In human erythrocyte survival studies, $25-40 \%$ of low ionic strength complementcoated erythrocytes were rapidly removed from the circulation, with a $t_{1}$ of about $30 \mathrm{~s}(2)$. This sequestration was temporary, and the cells began to reappear in the general circulation within $20 \mathrm{~min}$, often entirely reappearing in 3 days. In a patient with chronic cold agglutinin disease, sensitization of autologous erythrocytes in vitro with the patient's antibody produced a rapid clearance of the cells from the circulation, total reappearance within $24 \mathrm{~h}$, and thereafter a normal erythrocyte survival (1). Increasing the extent of complement coating eliminated approximately $30 \%$ of the cells, but those reappearing survived normally. Brown, Lachmann, and Dacie (3) studied the effect of human cold agglutinin on erythrocyte survival in rabbits and found that some of the sequestered erythrocytes were phagocytized in the livers and others released as damaged spherocytic cells. They concluded that the presence of fixed C3b was required for reticuloendothelial sequestration. Studies in guinea pigs have also stressed the importance of $\mathrm{C} 3 \mathrm{~b}$ in sequestration of complementcoated erythrocytes when complement-fixing antibody was present $(16,17)$, and these studies have recently been confirmed in man (18).

One membrane property postulated as important in erythrocyte survival is its net negative surface charge (19). In human erythrocytes, the negative charge is largely due to ionized neuraminic acid (20). Complement-fixation has been found to alter the net negative surface charge in heterologous systems of cells with complement and antibodies. Forrester, Dumonde, and Ambrose (11) studied the effect of rabbit antibody and guinea pig complement on mouse ascites tumor cells. Okada, Kojima, Yoshida, and Nishioka (10) found changes in surface charge of sheep erythrocytes using unfractionated rabbit antibody and the stepwise addition of purified guinea pig complement. In contrast to these studies, only human erythrocytes and proteins were used in our studies, and antibody did not remain

TABLE V

Correlation of Clinical Status of Three Patients with Cold Agglutinin Disease with Complement and Deformability Measurements

\begin{tabular}{|c|c|c|c|c|c|c|c|c|c|c|}
\hline \multirow[b]{2}{*}{ Patient } & \multirow{2}{*}{$\begin{array}{l}\text { Severity } \\
\text { of cold } \\
\text { intolerance }\end{array}$} & \multirow{2}{*}{$\begin{array}{l}\text { Hemo- } \\
\text { globin }\end{array}$} & \multirow{2}{*}{$\begin{array}{l}\text { Reticulo- } \\
\text { cytes }\end{array}$} & \multirow{2}{*}{$\begin{array}{c}\text { Total } \\
\text { bilirubin }\end{array}$} & \multirow{2}{*}{$\begin{array}{l}\text { Cold } \\
\text { agglutinin } \\
\text { anti-I titer* }\end{array}$} & \multicolumn{2}{|c|}{ Filtration time } & \multirow[b]{2}{*}{$\mathrm{C} 3 \mathrm{~b}$} & \multirow[b]{2}{*}{ C3d } & \multirow{2}{*}{$\begin{array}{l}\text { Immune } \\
\text { adherence }\end{array}$} \\
\hline & & & & & & $3 \mu m$ & $5 \mu m$ & & & \\
\hline & & $\mathrm{g} / 100 \mathrm{ml}$ & $\%$ & $m g / 100 m l$ & & \multicolumn{2}{|c|}{$s$} & \multicolumn{2}{|c|}{ molecules $/ R B C$} & $\%$ \\
\hline C. $\mathrm{McD}$. & Mild & 14.0 & 1 & 0.4 & 19,200 & 17 & 4.2 & 500 & 4,700 & $\mathbf{0}$ \\
\hline F. N. & Moderate & 14.1 & 5.3 & 1.4 & 16,000 & 116 & 4.2 & 7,000 & 319,167 & 32 \\
\hline J. B. & Severe & 11.4 & 5.8 & 3.0 & 128,000 & $400+$ & 16.4 & 10,065 & 534,470 & 32 \\
\hline
\end{tabular}

* Reciprocal titer at which agglutination was last positive.

$\ddagger$ Controls for $3-\mu \mathrm{m}$ filters $=11.2 \pm 2.9 \mathrm{~s} \pm 1 \mathrm{SD}(20)$; for $5-\mu \mathrm{m}$ filters, $4.1 \pm 0.3 \mathrm{~s} \pm 1 \mathrm{SD}(9)$, 
attached to the cells. We found no changes in either the net negative surface charge of complement-coated erythrocytes or differences in the influence of $\mathrm{pH}$ on electrophoretic mobility. However, although we found no changes in net negative surface charge of complement-coated human erythrocytes, local perturbations of membrane structure induced by complement could promote areas of increased and decreased anionic density, with the overall charge remaining constant.

The relationship of erythrocyte deformability to erythrocyte survival has been extensively explored and described (21). Changes in surface area to volume ratio, intracellular inclusions, or intrinsic membrane rigidity of erythrocytes, promote stasis in the microvasculature with subsequent destruction by the reticuloendothelial system. The effect of complement fixation of erythrocyte deformability is striking. Increasing amounts of complement, added either by low ionic strength, IgM cold agglutinins, or in vivo in patients with cold agglutinin disease, produced decreased erythrocyte deformability as measured in either a flow rate or positive pressure system. This was not caused by antibody since IgM cold agglutinin complement-coated cells had no demonstrable antibody on their surface. It was not believed to be caused by $\mathrm{C} 1$ or $\mathrm{C} 2$ because washing the cells with VBS-G-EDTA or incubating for $2 \mathrm{~h}$ at $37^{\circ} \mathrm{C}$ in VBS-G-M $\mathrm{M}^{++}$had no effect on their deformability. Further, these changes seemed directly related to levels of erythrocyte-bound C3 and the abnormalities were reversed by inactivation of $\mathrm{C} 3 \mathrm{~b}$. Three additional findings suggest that $\mathrm{C} 3 \mathrm{~b}$ was responsible for changes in erythrocyte deformability: (a) sequestration of in vivo complement-coated erythrocytes occurs in C6-deficient rabbits but not in C3-depleted rabbits (3) or guinea pigs $(16,17)$; $(b)$ the presence of a C3 inactivator is well described (22); and $(c)$ human erythrocytes coated with $\operatorname{IgM}$ antibody and $\mathrm{C} 3 \mathrm{~b}$ are rapidly cleared from the circulation, whereas those erythrocytes coated with antibody and $\mathrm{C} 3 \mathrm{~d}$ are not cleared (18). Incubation of the erythrocytes in VBS-G-M $\mathrm{M}^{++}$, a procedure that inactivates bound C5 (23), failed to correct the filtration abnormality. Other factors that are known to decrease erythrocyte deformability (21) were not found; ancillary studies showed no significant cellular changes or aggregation by phase microscopy, no size differences by mean corpuscular volume or osmotic fragility measurements, no intracellular inclusions, and no decreased ATP levels in the complement-coated erythrocytes. Although interaction between erythrocytes coated with $\mathrm{C} 3 \mathrm{~b}$ has been described (24), it was not seen in our test system. Therefore, the defect was believed to reside in the membrane.

The cause of the decreased deformability is not clear. C5 and C6 have been found on erythrocytes of patients with autoimmune hemolytic anemias without affecting erythrocyte survival or membrane integrity (25). By the stepwise addition of purified complement components, Polley, Müller-Eberhard, and Feldman (26) found an ultrastructural lesion in the erythrocyte membrane when the C5 stage was reached. The lesion was not removed by trypsin and therefore was felt to be intrinsic to the membrane and not an arrangement of complement molecules on the membrane. However, incubation of erythrocytes in buffer failed to correct the abnormality in filtration, and it is therefore unlikely that C5 plays a major role in the deformability changes. Complement has been alleged to affect membrane lipids $(27,28)$, but this work has not been confirmed by others (29-32). In any event, the rapidity of the correction in deformability upon incubation in serum makes it unlikely that extensive lipid changes play a role.

The presence of large amounts of complement on the erythrocyte membrane may interfere with deformability. Accretion of $\mathrm{C} 3 \mathrm{~b}$ in plaques may influence deformability by sheer bulk. When C3bINA (21) reacts with C3b (mol wt 185,000) to produce free C3c (mol wt 150,000) and bound C3d (mol wt 35,000), the membrane may regain some of its plasticity. The filtration time of complement-coated erythrocytes incubated in serum improved but never became normal. Large amounts of $\mathrm{C} 3 \mathrm{~d}$, as seen in the patients with chronic cold agglutinin disease, may interfere with erythrocyte deformability. In our three patients with chronic cold agglutinin disease, we found elevated levels of C3d and $\mathrm{C} 3 \mathrm{~b}$ on their erythrocytes, the latter correlating with increased immune adherence. These changes were found repeatedly despite careful sample collection. These changes probably reflect the sensitivity of the method used for estimating $\mathrm{C} 3 \mathrm{~b}$ and $\mathrm{C} 3 \mathrm{~d}$. With this assay, factors such as complement source would give different absolute numbers in different laboratories.

Decreased deformability of complement-coated erythrocytes could explain the difficulty these cells have in traversing the microvasculature. This stasis or delay in the microvasculature would prolong exposure to $\mathrm{C} 3 \mathrm{~b}$ receptors $(33,34)$ on macrophages and thereby promote immune adherence. If the erythrocyte becomes attached to a macrophage, it may be ingested or partially damaged. If not ingested, C3bINA cleaves off $\mathrm{C} 3 \mathrm{c}$, and the erythrocyte re-enters the circulation as a partially damaged spherocyte or a completely normal cell. The time-course of $\mathrm{C} 3 \mathrm{~b}$ inactivation is consistent with the clinical erythrocyte survival studies requiring $\frac{1}{2}$ to $2 \mathrm{~h}$ for the return of the sequestered cells in the circulation (1). These cells may contain immunologically identifiable complement components on their membrane but they are predominantly of the C3d type. 


\section{ACKNOWLEDGMENTS}

We wish to express our thanks to Sandra E. Dixon and Robert C. Payne for their technical assistance.

\section{REFERENCES}

1. Lewis, S. M., J. V. Dacie, and L. Szur. 1960. Mechanism of haemolysis in the cold-haemagglutinin syndrome. Brit. J. Haematol. 6: 154-159.

2. Mollison, P. L. 1965. The role of complement in haemolytic processes in vivo. Ciba Found. Symp. 323-339.

3. Brown, D. L., P. J. Lachmann, and J. V. Dacie. 1970. The in vivo behaviour of complement-coated red cells: studies in C6-deficient, C3-depleted and normal rabbits. Clin. Exp. Immunol. 7: 401-422.

4. Hartmann, R. C., and D. E. Jenkins, Jr. 1966. The "sugar water" test for paroxysmal nocturnal hemoglobinuria. N. Engl. J. Med. 275: 155-157.

5. Mardiney, M. R., and H. J. Müller-Eberhard. 1965. Mouse $\mathrm{B}_{1 \mathrm{c}}$-globulin: production of antiserum and characterization in the complement reaction. J. Immunol. 94: 877-882.

6. Borsos, T., and E. J. Leonard. 1971. Detection of bound C3 by a new immunochemical method. J. Immunol. 107: 766-771.

7. Logue, G. L., W. F. Rosse, and J. P. Adams. 1973. Complement-dependent immune adherence measured with human granulocytes: changes in the antigenic nature of red cell-bound $\mathrm{C} 3$ produced by incubation in human serum. Clin. Immunol. Immunopath. 1: 398-407.

8. Fuhrmann, G. F., and G. Ruhenstroth-Bauer. 1965. Cell electrophoresis employing a rectangular measuring cuvette. In Cell Electrophoresis. E. J. Ambrose, editor. Little, Brown, and Co., Inc., Boston. 22-25.

9. Lichtman, M. A., and R. I. Weed. 1970. Electrophoretic mobility and $\mathrm{N}$-acetyl neuraminic acid content of human normal and leukemic lymphocytes and granulocytes. Blood J. Hematol. 35: 12-22.

10. Okada, H., K. Kojima, T. O. Yoshida, and K. Nishioka. 1972. Electrokinetic behavior of intermediate cells in immune hemolysis. J. Immunol. 108: 59-64.

11. Forrester, J. A., D. C. Dumonde, and E. J. Ambrose. 1965. The effects of antibodies on cells. II. Changes in the electrophoretic mobility of ascites tumor cells treated with antibodies and complement. Immunology. 8: 37-48.

12. Gregersen, M. I., C. A. Bryant, W. E. Hammerle, S. Usami, and S. Chien. 1967. Flow characteristics of human erythrocytes through polycarbonate sieves. Science (Wash. D. C.). 157: 825-827.

13. Miller, L. H., S. Usami, and S. Chien. 1971. Alteration in the rheologic properties of Plasmodium knowlesiinfected red cells. A possible mechanism for capillary obstruction. J. Clin. Invest. 50: 1451-1455.

14. Kornberg, A. 1950. Reversible enzymatic synthesis of diphosphopyridine nucleotide and inorganic pyrophosphate. J. Biol. Chem. 182: 779-793.

15. Parpart, A. K., P. B. Lorenz, E. R. Parpart, J. R. Gregg, and A. M. Chase. 1947. The osmotic resistance (fragility) of human red cells. J. Clin. Invest. 26: 636640.

16. Schrieber, A. D., and M. M. Frank. 1972. Role of antibody and complement in the immune clearance and destruction of erythrocytes. I. In vivo effects of IgG and IgM complement-fixing sites. J. Clin. Invest 51: 575582.
17. Schrieber, A. D., and M. M. Frank. 1972. Role of antibody and complement in the immune clearance and destruction of erythrocytes. II. Molecular nature of IgG and IgM complement-fixing sites and effects of their interaction with serum. J. Clin. Invest. 51: 583589.

18. Atkinson, J. P., and M. M. Frank. 1974. Studies on the in vivo effects of antibody interaction of $\operatorname{IgM}$ antibody and complement in the immune clearance and destruction of erythrocytes in man. J. Clin. Invest. 54: 339-348.

19. Danon, D. 1966. Biophysical aspects of red cell aging. 11th Congress of International Society of Hematology. Grune and Stratton Inc., New York. 394-405.

20. Eylar, E. H., M. A. Madoff, O. V. Brody, and J. O. Oncley. 1962. The contribution of sialic acid to the surface charge of the erythrocyte. J. Biol. Chem. 237: 1992-2000.

21. Weed, R. I. 1970. The importance of erythrocyte deformability. Am. J. Med. 49: 147-150.

22. Ruddy, S., and K. F. Austen. 1971. C3b inactivator of man. II. Fragments produced by $\mathrm{C} 3 \mathrm{~b}$ inactivator cleavage of cell-bound or fluid phase C3b. J. Immunol. 742-750.

23. Cooper, N. R., and H. J. Müller-Eberhard. 1970. The reaction mechanism of human $\mathrm{C5}$ in immune hemolysis. J. Exp. Med. 132: 775-793.

24. Petz, L., H. H. Fudenberg, and D. Fink. 1971. Immune adherence reactions of human erythrocytes sensitized with complement in vitro and in vivo. J. Immunol. 107: 1714-1722.

25. Kerr, R. O., A. P. Dalmasso, and M. E. Kaplan. 1971. Erythrocyte-bound $\mathrm{C} 5$ and $\mathrm{C} 6$ in autoimmune hemolytic anemia. J. Immunol. 107 : 1209-1210.

26. Polley, M. J., H. J. Müller-Eberhard, and J. D. Feldman. 1971. Production of ultrastructural membrane lesions by the fifth component of complement. J. Exp. Med. 133: 53-62.

27. Dumonde, D. C., L. Bitensky, G. J. Cunningham, and J. Chayen. 1965. The effects of antibodies on cells. I. Biochemical and histochemical effects of antibodies and complement on ascites tumour cells. Immunology. 8: 25-26.

28. Guttler, F., and J. Clausen. 1969. Changes in lipid pattern of HeLa cells exposed to immunoglobulin $\mathrm{G}$ and complement. Biochem. J. 115: 959-968.

29. Phillips, G. B., and E. Middleton, Jr. 1965. Studies on lysolecithin formation in immune hemolysis. J. Immunol. 94 : 40-46.

30. Smith, J. K., and E. L. Becker. 1968. Serum complement and the enzymatic degradation of erythrocyte phospholipid. J. Immunol. 100: 459-474.

31. Inoue, K., and S. C. Kinsky. 1970. Fate of phospholipids in liposomal model membranes damaged by antibody and complement. Biochemistry. 9: 4767-4776.

32. Hesketh, T. R., S. N. Payne, and J. H. Humphrey. 1972. Complement and phospholipase C lysis of lipid membranes. Immunology. 23: 705-711.

33. Lay, W. H., and V. Nussenzweig. 1968. Receptors for complement on leukocytes. J. Exp. Med. 128: 991-1007.

34. Mantovani, B., M. Rabinovitch, and V. Nussenzweig. 1972. Phagocytosis of immune complexes by macrophages. Different roles of the macrophage receptor sites for complement (C3) and for immunoglobulin (IgG). J. Exp. Med. 135 : 780-792. 